11 Joplin, G. A., J. geol. Soc. Aust., 15, 275-294 (1968).

12 Jakes, P., and White, A. J. R., Tectonophysics, 8, 223-236 (1969).

13 Dickinson, W. R., Rev. Geophys. Space Phys., 8, 813-860 (1970).

14 Jakes, P., and White, A. J. R., Bull. geol. Soc. Am., 83, 29-40 (1972)

Hyndman, D. W., Petrology of Igneous and Metamorphic Rocks, 533 (McGrawHill, New York and San Francisco, 1972).

6 Dickinson, W. R., Am. J. Sci., 272, 551-576 (1972)

7 Dickinson, W. R., J. geophys. Res., 78, 3376-3389 (1973).

Burke, K. C., and Dewey, J. F., in African Geology (edit. by Dessauvagie, T. F. J. and Whiteman, A. J.), 538-608 (University of Ibadan, 1971).

${ }^{9}$ Clifford, T. N., Notes \& Serv. geol. Maroc, 236; Coll. Intern. CNRS (Paris), 192, 29-39(1972).

\section{A novel beryllosilicate phase containing 3-coordinate beryllium $\left(\mathrm{Rb}_{2} \mathrm{Be}_{2} \mathrm{Si}_{2} \mathrm{O}_{7}\right)$}

BERYLLOSILICATES are normally framework structures, with $\mathrm{Be}$ in tetrahedral coordination, similar to Si (ref. 1), and the structural role of $\mathrm{Be}$ can be compared with that of $\mathrm{Al}$ in the aluminosilicates. We report here on the preparation and $\mathrm{X}$-ray crystal structure determination of $\mathrm{Rb}_{2} \mathrm{Be}_{2} \mathrm{Si}_{2} \mathrm{O}_{7}$, which contains planar $\mathrm{BeO}_{3}$ groups. Such coordination is unusual for beryllium, and, in complex oxides, has apparently been found previously only in $\mathrm{Y}_{2} \mathrm{BeO}_{4}$ (ref. 2), $\mathrm{Ca}_{12} \mathrm{Be}_{17} \mathrm{O}_{29}$ (ref. 3), and $\mathrm{K}_{2} \mathrm{BeO}_{2}$ (ref. 4).

The compound $\mathrm{Rb}_{2} \mathrm{Be}_{2} \mathrm{Si}_{2} \mathrm{O}_{7}$ was prepared by solid-state reaction between appropriate quantities of $\mathrm{Rb}_{2} \mathrm{CO}_{3}, \mathrm{BeO}$ and quartz. A single crystal was selected from a sample which had been heated at $950^{\circ} \mathrm{C}$ for three days. The orthorhombic cell dimensions are

$$
a=8.92 \AA ; b=8.32 \AA ; c=5.15 \AA
$$

The intensity data, obtained from a Hilger and Watts Y-190 linear diffractometer with MoK $\alpha$ radiation, indicated a body-centred space group. The solution of the vector (Patterson) map indicated the space group to be $12 \mathrm{~mm}$. Later, a few, rather weak, additional reflections were observed on films, and the space group P2nn was adopted. The complete solution of the structure using vector and Fourier methods, followed by least squares refinement, has so far given values of $R=0.071$, over 241 independent reflections.

The structure consists of $\mathrm{Si}_{2} \mathrm{O}_{7}$ groups, linked at their corners by $\mathrm{Be}$, to form an infinite framework anion of empirical formula $\left[\mathrm{Be}_{2} \mathrm{Si}_{2} \mathrm{O}_{7}\right]^{2-}$. Large cavities contain two crystallographically distinct $\mathrm{Rb}^{+}$ions, which have 13 and 14 nearest neighbour oxygen atoms (within $3.8 \AA$ ), respectively. In the planar $\mathrm{BeO}_{3}$ group, $\mathrm{Be}-\mathrm{O}$ distances are around $1.54 \AA$, which is about $0.11 \AA$ shorter than those in tetrahedral $\mathrm{BeO}_{4}$ (ref. 5); $\mathrm{O}-\mathrm{Be}-\mathrm{O}$ angles are close to $120^{\circ}$.

$\mathrm{X}$-ray powder diffraction data suggest that $\mathrm{Cs}_{2} \mathrm{Be}_{2} \mathrm{Si}_{2} \mathrm{O}_{7}$ is isostructural with $\mathrm{Rb}_{2} \mathrm{Be}_{2} \mathrm{Si}_{2} \mathrm{O}_{7}$

\section{R. A. HowIE}

A. R. WEST

Department of Chemistry,

University of Aberdeen,

Aberdeen AB9 2UE, UK

Received December 9, 1975; accepted January 2, 1976.

1 Bragg, W. L., and Zachariasen, W. H., Z. Kristallogr. Miner., 72, 518 (1930).

2 Harris, L. A., and Yakel, H. L., Acta crystallogr., B22, 354 (1967).

3 Idem., ibid., B20, 295 (1966).

4 Kastner, P., and Hoppe, R., Naturwissenschaft, 61, 79 (1974) International Tables for X-ray Crystallography, III, second ed, 260 (Kynoch,
Birmingham, 1968).

\section{Coccolith blooms in the Kimmeridge Clay and origin of North Sea Oil}

IN this paper I suggest that Kimmeridge Clay oil shales (and therefore much of the oil in the North Sea) were formed from algal blooms, in an environment between open ocean, and an enclosed marine basin. These conditions favour the production of such blooms, which by deoxygenating and poisoning the water, could temporarily create bottom conditions suitable for the formation of organic-rich sediment.
Thin coccolith-rich bands were first noted in the Kimmeridge Clay by Downie ${ }^{1}$, at four levels in the cliff sections near Kimmeridge Bay, Dorset. The most prominent of these bands, the White Stone Band, was subsequently recorded in boreholes in Hampshire, Surrey, Sussex ${ }^{2}$ and Norfolk ${ }^{3}$.

Coccolith-rich bands of a similar nature have recently been recorded at three levels in a borehole at Donington on Bain, Lincolnshire, each level corresponding with one of the higher levels in Dorset. Re-examination of borehole material from Surrey and Norfolk has shown that the same three horizons are present in Surrey, and that the lowest two of these are present in Norfolk (Fig. 1). Thus, these coccolith-rich bands occur over an area where the Kimmeridge Clay varies in thickness from $<100 \mathrm{~m}$ to $>500 \mathrm{~m}$, and which embraced both the stable margins and the more rapidly subsiding parts of the basin of deposition.

The coccolith-rich bands are readily recognisable in borehole cores by their pale colour and lightness in weight, and at outcrop by their almost white weathering patina. In Dorset the thickest band is $\sim 0.5 \mathrm{~m}$ thick, but elsewhere the three bands are each generally $<0.1 \mathrm{~m}$ thick. The coccolith contents of these bands ranges from $60-98 \%$ of the calcium carbonate fraction of the rock $(30->50 \%$ of the whole rock). Most other Kimmeridge Clay lithologies contain $<3 \%$ coccoliths/whole rock, although some of the more calcareous clays have yielded up to $12.5 \%$ coccoliths/whole rock.

The coccolith-rich bands are generally composed almost wholly of one species, Ellipsagelosphaera britannica (Stradner) ${ }^{3}$. Even now, seasonal blooms of coccoliths consisting largely of one species occur from time to time over large areas of the North Sea ${ }^{4}$. Such blooms characteristically form in seas which are rich in land-derived nutrients and are to some degree landlocked so that, although they remain a fully marine environment, their salinities are slightly lower than those of the open oceans. The persistence and composition of the thin coccolithrich beds in the Kimmeridge Clay suggests that they were formed from similar blooms.

In addition to their usefulness as stratigraphical marker beds the coccolith-rich bands may provide an insight into the conditions of depositional environment in which the Kimmeridge Clay oil shales were deposited, since each of the coccolith-rich bands recorded to date occurs in close association (usually interlaminated) with oil shales.

Although they vary considerably in thickness, the Kimmeridge Clay sequences in Dorset, Surrey and Norfolk can be matched with one another in lithological and faunal detail ${ }^{3}$, suggesting that ecologically similar environments existed over much of southern England, in spite of great variations in rate of subsidence of the sea floor. The distribution of the Kimmeridge Clay lithologies and fauna, mostly pelagic ammonites and benthonic bivalves, including oysters, preserved in calcite, suggests accumulation in a relatively shallow marine environment on a broad continental shelf. The oil shales contain a richer and more abundant fauna than any other lithology in the Kimmeridge Clay. They are characterised by bedding planes crowded with one or two species of small bivalve or ammonite preserved in either calcite or pyrite, and by small gastropods, phosphatised fish debris and faecal pellets, abundant Foraminiferida and, locally, by pyritised plates of the free-swimming crinoid Saccocoma.

In Dorset the oil shales contain $\leqslant 40 \%$ of brown organic matter which Forsman ${ }^{5}$ has described as composed mostly of kerogen. This kerogen occurs largely as laths of amorphous organic matter (AOM) but is rich in palynomorphs such as dinoflagellates ${ }^{1}$. Cosgrove ${ }^{6}$ recorded abnormally high iodine and bromine contents in some of the oil shales from the Kimmeridge Clay in Dorset, and has related this to the abundance of microplankton present.

According to Trask ${ }^{7}$, few modern typically marine sediments contain more than $10 \%$ of organic matter; near-shore sediments generally contain between $1 \%$ and $8 \%$ and open-ocean sediments $\sim 1 \%$. Kaplan and Rittenberg ${ }^{B}$ state that the 